\title{
TEXAS BIO-NUCLEAR RADIOCARBON MEASUREMENTS I
}

\author{
JOHN B. CHANDLER, RUSSELL KINNINGHAM, DON S. MASSEY \\ Kaman Instruments Formerly Texas Bio-Nuclear \\ A Division of Kaman Aircraft Corporation \\ P. O. Box 9431, Austin 17, Texas
}

INTRODUCTION

Introduction-Texas Bio-Nuclear is a proprietary establishment engaged in offering $\mathrm{C}^{14}$ dating by the liquid-scintillation method as a service to those institutions and individuals who have a need for such a service. The Laboratory began actual dating operations in December 1961. The first few months were devoted to processing check samples in order to establish the reliability of the system. The dates listed below are not inclusive of all our dating, since the dates we furnish our clients are their property and the publishing of this information is their decision.

Sample types and pretreatment-The types of samples submitted to our laboratory vary widely, some are: natural gases, charcoal, wood, terrestrial shells, ivory, textile, limestone, humic soil, and mixtures of soil and charcoal. Sample pretreatment follows the usual method: 1) removal of gross foreign matter by hand, 2) distilled-water rinse, 3) hot $0.1 \mathrm{~N} \mathrm{NaOH}$ bath for ten minutes, 4) distilled-water rinse, 5) hot $0.1 \mathrm{~N} \mathrm{HCl}$ bath for ten minutes, 6) a final distilled-water rinse. This routine is varied occasionally for samples of unusual nature. Ultrasonic cleaning has been used with some success on textile and shell samples.

Chemical conversion-The sample is burned to $\mathrm{CO}_{2}$ and synthesized to benzene in a manner similar to that used at the University of Texas (Stipp, et ai., 1962).

The overall efficiency of the chemical conversion of sample carbon to benzene carbon is ca. 50\%. Primary scintillator (PBD) and secondary scintillator (POPOP) are dissolved in the sample benzene, which is placed for counting, in a $4 \mathrm{ml}$ cylindrical type vial. The vial used is of frosted glass. Through our investigations we have found the combination of this vial type and the scintillators mentioned above produce improved pulse-height resolutions, thus increasing the counting efficiency for $\mathrm{C}^{14}$. It is sometimes necessary to add "dead" reagent grade benzene to bring the vial up to volume when the sample benzene is not sufficient.

Sample counting and counting equipment-The counter currently in use is our modified version of the commercially available Packard Tri-Carb Liquid Scintillation Spectrometer. The unit is operated under modified operating conditions. The detector unit of the system is placed in a freezer and operated at a temperature of $4.5^{\circ}$ to $5.5^{\circ} \mathrm{C}$. The balance of the electronic components are installed in a smaller freezer operating at ca. $60^{\circ} \mathrm{F}$. The effects of these modifications, including the use of the special vial, have been: 1) reduced background, 2) greater instrument stability, and 3) increased counting efficiency. 
The entire counting system is installed in a document-storage vault whose walls, ceiling, and floor are of 8-in. thick concrete.

The modern standard presently in use is $95 \%$ of the activity of the NBS oxalic-acid standard. This produces a gross uncorrected count of 27.34 counts/min. Background for an equal volume of modern sample is 3.2 counts/min. Ages are calculated using the Libby half life of $5568 \mathrm{yr}$, with A.D. 1950 as the reference year.

Acknowledgements - We acknowledge our appreciation of the technical guidance of Dr. John K. Kirby, former Director of Laboratories at Texas BioNuclear; M. C. Davis, former Research Chemist at Texas Bio-Nuclear; and the $\mathrm{C}^{14}$ dating staff at Texas Bio-Nuclear.

\section{SAMPLE DESCRIPTIONS}

\section{GEOLOGIC SAMPLES}

\section{A. Southwestern United States}

\section{TBN-307-1. Rich Lake, Texas}

$$
17,756 \pm 358
$$

15,806 в.C.

Limestone from an exposed bluff of Tahoka sediments at the NE corner of Rich Lake, Terry County, Texas $\left(33^{\circ} 17^{\prime} \mathrm{N}\right.$ Lat, $102^{\circ} 12^{\prime} \mathrm{W}$ Long). Coll. 1961 and subm. by F. Wendorf and J. Hester, Mus. of New Mexico, Santa Fe, New Mexico. Comment (J.H.) : this sample is the lowest of three freshwater limestones exposed at this site and should date near the beginning of the Pleistocene. This sample may have been contaminated by groundwater. A comparable sample has been dated at 26,500 \pm 800 (Lamont VII, L-513B).

\section{TBN-307-2. White Lake, Texas}

$18,612 \pm 347$

Limestone from exposed clay bluff at NW corner of White Lake in Muleshoe Natl. Wildlife Refuge, Bailey County, Texas $\left(33^{\circ} 55^{\prime} \mathrm{N}\right.$ Lat, $102^{\circ} 47^{\prime} \mathrm{W}$ Long). Coll. 1961 and subm. by J. Harbour and J. Hester. Comment: sample is from the upper limestone marker bed within late Pleistocene Tahoka clays. The beds antedate human occupation of the area and this limestone should correlate with the dated upper bed at Rich Lake, Texas; 17,400 \pm 600 (Lamont VII, L-513-A).

\section{ARCHAEOLOGIC SAMPLES}

\section{A. Northwestern United States}

\section{TBN-304-2. Birch Creek, Idaho}

Charcoal (no. 25537) from Feature 6, Veratic Cave, a well-stratified rockshelter near Blue Dome in the Birch Creek Valley of eastern Idaho (44. $05^{\prime} \mathrm{N}$ Lat, $112^{\circ} 55^{\prime}$ W Long). Subm. by E. H. Swanson, Idaho State College Mus., Pocatello, Idaho. Comment: this is one of a large series of $\mathrm{C}^{14}$ samples collected during the 1960-61 excavations at various sites in the Birch Creek 
Valley; its stratigraphic position was earlier than UCLA-161 and UCLA-162 (UCLA II), which dated $5870 \pm 120$, and $5670 \pm 120$ respectively, but probably not much older. The calculated date agrees closely with the previous estimate.

\section{Weis Rockshelter series, Idaho}

This is a large, stratified, continuously occupied site at Camas Prairie in $\mathrm{N}$ Idaho $\left(45^{\circ} 55^{\prime} \mathrm{N}\right.$ Lat, $116^{\circ} 20^{\prime} \mathrm{W}$ Long). Enclosed in the deposits is a layer of Mt. Mazama ash, which separates a component of Old Cordilleran culture from a subsequent component of the Cold Springs horizon in the Columbia Plateau (Butler, 1961, 1962). However, redeposited volcanic ash was also found in the deposits enclosing the Old Cordilleran component, and this raised a question as to the antiquity of the earlier deposits and cultural materials which they enclosed. $\mathrm{C}^{14}$ samples of the same type were selected from the earliest and latest of this early series of deposits as a means of examining the problem further. Coll. and subm. by B. R. Butler, Idaho State College Mus.

\section{TBN-319. Substratum 5g}

$7340 \pm 140$

5390 в.c.

Charcoal and humus from substratum $5 \mathrm{~g}$, earliest of the Old Cordilleran components at the site.

\section{TBN-322. Substratum $5 c$}

$$
4650 \pm 70
$$
Cordilleran components.

General Comment (B.R.B.) : provided the layer of Mazama Ash noted above does not represent redeposition from local sources, the two dates are ca. 2000 yr younger than expected. However, the dates agree closely with respect to the relative stratigraphic positions of the two samples and with an independently calculated rate of accumulation of deposits at the site. This has led to reexamination of the deposits in question, the results of which will be published in Butler, 1962.

\section{B. Southwestern United States}

\section{TBN-306-3. Navajo Reservoir, New Mexico}

$2191 \pm 264$

241 B.c.

Wood charcoal (field specimen no. 4195-106-27) occurring in an oven fill of Feature 106; 0 to $1.0 \mathrm{ft}$ above floor; Site LA $4195\left(36^{\circ} 58^{\prime} \mathrm{N}\right.$ Lat, $107^{\circ} 26^{\prime}$ 33" W Long), San Juan County, New Mexico. Coll. 1961 and subm. by A. E. Dittert, Jr., Mus. of New Mexico. Comment: burials and associated pottery in the oven fill are of the Sambrito phase. This oven fill is overlain by Rosa phase materials of the period A.D. 700 to 900. Sample should date the Sambrito phase remains which occur stratigraphically between the Los Angeles Pinos phase (ca. A.D. 1 to 400) and the Rosa phase (A.D. 700 to 900). Date obtained appears to be too early. 


\section{TBN-311. Caddo County, Oklahoma}

Mammoth tusk ivory (no. 400-36) in fragmentary condition from a Pleistocene marsh deposit exposed by a permanent stream in the bottom of a $50 \mathrm{ft}$ deep arroyo in Caddo County, Oklahoma (1 mi E of $34^{\circ} 57^{\prime} 30^{\prime \prime} \mathrm{N}$ Lat, $98^{\circ} 17^{\prime} 30^{\prime \prime}$ W Long). Coll. 1961 and subm. by A. D. Anderson, Mus. of the Great Plains, Lawton, Oklahoma. Comment (A.D.A.) : sample was associated with Paleo-Indian projectile points and should date a period of association between extinct Pleistocene fauna and Paleo-Indian in Oklahoma. This date is obviously too recent for mammoth. The sample was in crumbly condition, and was probably contaminated by stream water and exposure to weather.

\section{Central America}

\section{Barton Ramie series, British Honduras}

Samples from the Barton Ramie site ( $17^{\circ} 15^{\prime} \mathrm{N}$ Lat, $89^{\circ} \mathrm{W}$ Long), in the Belize Valley near the Guatemala border in British Honduras. Coll. 1962 and subm. by G. R. Willey, Peabody Mus., Harvard Univ., Cambridge, Massachusetts.

\section{TBN-310-1. Mound BR-155}

$4016 \pm 118$ 2066 B.C.

Charcoal-earth mixture (no. 1006) from a fire area in Mound BR-155, Cut 1 , from the 1.3 to $1.5 \mathrm{~m}$ level.

\section{TBN-310-2. Mound BR-123, fire area $\quad 3414 \pm 118$}

Charred maize-earth mixture (no. 1766) from a fire area between Floors $\mathrm{D}$ and $\mathrm{E}(\mathrm{S})$ in Mound BR-123.
TBN-310-3. Mound BR-123, Oven fill
$4155 \pm 153$ 2205 в.C. BR-123.

Charcoal-earth mixture (no. 1676) from oven fill, Section 2 of Mound General Comment (G.R.W.) : the archaeological context of TBN-310-1 and TBN-310-3 is the Barton Creek phase of the Late Pre-Classic period in the Maya Lowlands and these samples should date this period. The context of TBN-310-2 is Late Classic period, Spanish Lookout phase and should date this period. The dates appear to ca. $1500 \mathrm{yr}$ too early in each instance. However, it is interesting to note that TBN-310-2, which was placed archaeologically later than the others, is ca. $600 \mathrm{yr}$ later according to these dates.

\section{Chichen Itza series, Yucatan, Mexico}

Three wood samples were taken from two buildings at Chichen Itza $\left(20^{\circ}\right.$ $41^{\prime} \mathrm{N}$ Lat, $88^{\circ} 34^{\prime} \mathrm{W}$ Long), Yucatan, Mexico. Two samples were taken from "La Iglesia" of the Las Monjas complex, and a supplementary sample was taken from the "Red House" or "Chicchanchob." Coll. 1962 by E. W. Andrews, Middle Amer. Research Inst., Tulane Univ., New Orleans, Louisiana, and David Bolles; subm. by J. S. Bolles, 14 Gold St., San Francisco 11, California. 


\section{TBN-313-1. La Iglesia I}

Wood, presumably sapote, taken from a beam-stub in a series of five small beams $252 \mathrm{~cm}$ above floor level along $W$ wall. The stub of the fourth beam, $99 \mathrm{~cm}$ from the $\mathrm{S}$ corner of $\mathrm{W}$ wall, was removed for this sample.

\section{TBN-313-2. La Iglesia II}

$$
\begin{array}{r}
1350 \\
\text { A.D. } 600
\end{array}
$$

Wood, presumably sapote, taken from a beam-stub in a series of beams $380 \mathrm{~cm}$ above the floor along $W$ wall. Fragments were removed from the third beam $\mathrm{N}$ to comprise this sample.

\section{TBN-313-3. Red House or Chicchanchob}

$$
\begin{array}{r}
1340 \pm 60 \\
\text { A.D. } 610
\end{array}
$$

Wood, presumably kiichi, taken from the southernmost beam of the upper tier of beams in this structure.

General Comment (E.W.A.) : samples taken from "La Iglesia" are contemporaneous with the original construction of the building. The sample from the "Red House" lacks the certainty of the "La Iglesia" samples, but the possibility is believed to be very remote that it dates later than the original construction of the "Red House."

\section{Bilbao series, Escuintla, Guatemala}

These samples are from the Bilbao site, Finca Las Ilusiones, Santa Lucia Cotzumalhuapa, Escuintla, Guatemala $\left(14^{\circ} 20^{\prime} \mathrm{N}\right.$ Lat, $91^{\circ} 0^{\prime} \mathrm{W}$ Long). Coll. 1962 by R. Ritzenthaler and L. A. Parsons; subm. by S. F. de Borhegyi, Milwaukee Public Mus., Milwaukee, Wisconsin.

\section{TBN-315-1. Monument 21, platform rubble}

$$
\begin{array}{r}
1423 \\
\text { A.D. } 527
\end{array}
$$

Charcoal from 4 to $5 \mathrm{ft}$ below surface, Group B, Mound 2, Monument 21, excavation unit 4. Comment: sample was found among the stone rubble of a platform sloping away from the front of Monument 21 (carved in Santa Lucia Cotzumalhuapa style). The sample was associated with pottery sherds which include assumed Late Pre-Classic and Early Classic types, and should date the construction of the rubble platform, associated pottery types, and possibly carving of the monument.

\section{TBN-315-2. Esperanza Nursery}

$$
503 \pm 70
$$

Charcoal from 3.5 to $5.0 \mathrm{ft}$ below surface, Test Pit no. 2 at Esperanza Nursery locality ( $0.5 \mathrm{mi} \mathrm{N}$ of Acropolis). Comment: sample was associated with a concentrated refuse heap of sherds of supposedly Late Classic context. The sherds include San Juan Plumbate, Tiquisate, and tall redware vases of specular hematite. The charcoal fragments were scattered throughout the refuse heap rather than in a single spot. Since the associated pottery includes types assumed to be of a single period, the charcoal should have been deposited within a relatively short span of time, and should date the deposition of the above pottery types. 


\section{Middle East}

\section{TBN-320-2. Rayy, Iran (Persia)}

Silk textile from burial shroud (sample no. RN-6948) taken from a grave in the NW area of a small hill, Nakkareh Khaneh, in the outskirts of Rayy, 6 $\mathrm{km} \mathrm{SE}$ of Teheran, Iran ( $35^{\circ} 45^{\prime} \mathrm{N}$ Lat, $51^{\circ} 45^{\prime} \mathrm{E}$ Long). Coll. 1936 by E. F. Schmidt; subm. by W. J. Young, Mus. of Fine Arts, Boston, Massachusetts. Comment: the Rayy excavations provide dates from the 8th century A.D. to A.D. 1220, and sample should date this type of silk and burial. It is possible this grave may have been disturbed, for it was not a sealed deposit.

Date list:

\section{REFERENCES}

$$
\begin{array}{ll}
\text { Lamont VII } & \text { Olson and Broecker, 1961 } \\
\text { UCLA II } & \text { Fergusson and Libby, } 1963
\end{array}
$$

Butler, B. R., 1961, The old Cordilleran culture in the Pacific Northwest: Occasional Papers of the Idaho State College Mus., no. 5.

1962, Contributions to the Archeology of the Columbia Plateau: Occasional Papers of the Idaho State College Mus., no. 9, in press.

Fergusson, G. J., and Libby, W. F., 1963, UCLA radiocarbon dates II: Radiocarbon, v. 5 , p.

Olson, E. A., and Broecker, W. S., 1961, Lamont Natural Radiocarbon Measurements VII: Radiocarbon, v. 3, p. 141-173.

Stipp, J. J., Davis, E. M., Noakes, J. E., and Hoover, T. E., 1962, University of Texas radiocarbon dates I: Radiocarbon, v. 4, p. 43-50. 